\title{
So Long a Letter: Understanding the Missionary Narrative of a Polygamy Victim
}

\author{
Reuben Kehinde Akano, \\ Languages and Literary Studies, College of Humanities, Management and Social Sciences Kwara State \\ University, Malete, Nigeria
}

\begin{abstract}
This paper dwells on the analysis of So Long a Letter, a novella by Mariama Ba, a Senegalese woman with a view to bringing out the issue of polygamy as thematically presented in the work. The thematic analysis of So Long a Letter is an obvious one. It solely condemns polygamy and it devastating effects on the girl-child in a cultural context and as constraints on the happiness of couples who are usually separated. Feminism in its various strands was adopted as the theoretical framework. Women and men are guilty of polygamy as they collaborate in promoting the practice using religious and cultural platform while these actors have different motives.
\end{abstract}

Keywords: Africa, Feminism, Polygamy, Womanism,

\section{Introduction}

Polygamy, no doubt remains a great social challenge to the African woman. The practice evolves from cultural and religious bias as may be adumbrated by both men and women practioners. The need to elucidate on the fight against various injustices and deprivations suffered by women all over the globe and in particular and of special interest in Africa is the focus of this paper. From various postulations, opinions and viewpoint, all efforts at addressing women's unsavory conditions are referred to as feminism. Feminism has always been considered both as a theory and a movement designed or embarked upon to whip up global support for women and condemnation or sentiment against injustice, unfair treatment and 'persecution' done to the womenfolk. In several works of art, feminism or issues relating to women's condition have been taken up from the perspective of the experiential account given by women themselves as a direct or first-hand narrative. Both male and female writers of African descent have taken up the challenge. For instance, the issue of outcast or Osu, in Igbo land of the Southeastern part of Nigeria is presented as the thematic engagement of Efuru by Flora Nwapa; Zynab Alikali is not quite different as her The Still Born captures the dream of emancipation, triumph and elevation of a woman is often being truncated by cultural or traditional conjectures and the attendant unwarranted rejection, scorn or judgmental reaction of society castigating or condemning the women prey or victim; Even the rise of women as an economic success, educational icons and so on as often resented atimes in an African traditional setting as an aberration based on the perspective of in-laws comes open in Chiamamanda Adichie's Purple Hibiscus among others.

There is the male perception of feminism which is equally split in-between. Yambo Ouloguem's Bound to Violence presents the image of women as sexual prey in a traditional cultural caste system of Africa while Chinua Achebe's Things Fall Apart relegates women culturally as second fiddle who should not be heard at all. Yet we have male writers such as Femi Osofissan, and Sembene Ousmane, playwright and novelist in Morountodun and God's Bits of Wood who present a dignifying image of the women as activists and agents of transformation in society. Thus in the context of experiential narrative, practical incidents of women abuse, excessive male domination or chauvinism, sexual pride, religious practices which subjugate women, societal prejudice and women inferiority notion are presented in creative works as cases of women for women, women against women or men for or against women.

In a similar vein, feminism is being championed as an ideology or a movement by women and men alike. This is a doctrinal approach to drumming up support for women liberation; it advocates equal right for women. Men and women as feminists championing the cause through campaign, symposia, sensitization, wakeup call against all perceived ill-treatment, imagined abuse or injustice done to women. This theoretical approach to feminist movement is all-encompassing, more general in outlook and reference, yet fluid and collaborative. It is the practical or pragmatic translation, demonstration or exemplification of these theories, theses, syntheses, postulations or viewpoint and sentiment or vituperations that are represented in creative works.

So Long a Letter exemplifies an outburst and a campaign by a woman as representative of the oppressed women under a polygamous set-up. The author condemns polygamy by highlighting and exposing the many ugly sides of the practice. The author calls the attention of the world to the plight of fellow women in a 
polygamous set-up; one of the evils of polygamy is the physical separation and the emotional agony the female spouses are usually subjected to throughout the remainder of their life. This paper is written to further raise the tempo of awareness and sustain the level of fight against women denials via polygamous practice.

\section{Strands of Feminism}

There have been several approaches to defining or advocating feminism by different scholars or schools. These are not unconnected with shades of abuse, injustice, oppression, persecution, deprivation or denial that the women prey or victim often falls. So in an attempt to capture the complex whole of discomfort, neglect, disrepute or stigmatization that a woman often faces, there has to be other angles to illuminating the concept. Simply put, feminism is about women, the belief that women should have equal rights and opportunities as men. Joseph (99) refers to feminism as an ideology of social commitment to the struggle for female liberation in society through conscious and collective effort. Chukwuma (ix) is not quite different in his opinion as he asserts that feminism as a theory elevates individuality, recognition and equal opportunity for women. Naolim(28) defines feminism as an identity which rallies support for the claim of women for equal rights with men in the aspects of legal, political, economic, social and material matters giving them a source of self-worth as contributing members.

The above definitions, in actual sense reflect postulations by the various schools on what constitutes strands of feminism. As earlier remarked feminism covers all types of ill-treatment and subjugation a women may suffer under different canopies of religion, culture, politics, education, sociology, attitude, environment etc. Thus these phases of women condition truly necessitates plethora of definitions or opinions and theories by scholars in a bid to adequately and appropriately capture the scope of feminism. Katharine S. et al (2008) collaborate this further to justify the preponderance of viewpoint:

Feminist enquiry is complex, comprehensive and fluid: it is much about formulating and researching questions of fact as it is about exploring those of values and policy, thereby covering the conceptual and methodological ground of communication research and theory (PP 504)

Feminism stems from or reflect incidents or perspectives from which individual scholar, group or society perceive women subjugation, abuse, oppression and deprivation. These postulations, definition or opinions are as well approaches to tackling such.

Of all strands of feminist schools, cultural feminism appears foremost and generic interms of tracing the epistemological precept of the unfair treatment given to women the world over from the primordial time. Cultural practices spell out implications for interpersonal relationship, attitude and identity. Our behavioral tendencies are often products of our nature and nurture. More of the abuse, sexist pride, deprivation women are perceived to be going through evolve from cultures. Anzaldua and Hill-Collins (1990) argue that "the norms, values and practices often spring from the dominant culture which seek to impose on everyone"'. Every culture may have undergone evolution over the years but inspite of that, virtual manifestation of the perceived antiwomen practices are entrenched in belief and practice. The notion: foregrounds the diasporic experiences of women (globally) of African descent, finding links transitionally between Africa, the United States, the Caribbean, and Latin America. African-American women often find that they have more in common with men from their communities than with white American, Asia or European women and they sometimes organize around diasporic issues that would otherwise be overlooked such as forced marriage, female circumcision, or neo-colonialism.

Cultural practices are at the bottom of feminist movement all over and particularly Africa as all facts or signpost of women denial and deprivation, oppression or subjugation stem from cultural prejudices. This notion is often referred to as womanism or African feminism.

The Marxist feminist opinion takes off from cultural feminism as it identifies patriarch (male domination) and capitalism as the bane and springboard of anti- woman opportunities and freedom. The Marxist-Feminist fingers capitalists and men as exploiters of women through chauvinism, patriarchy and undue profit or commodification. They are closely followed by the radical feminists who identify such social cum biological roles such as childbearing, gender image and sexual status as the basis of woman deprivation and relegation. This position is summed up by the psychoanalytic feminists as they identify psychological traits in women such as sympathetic and gentle nature which men often decode to be their "weak nature".

Other Feminists theories are the liberal and Eco- feminist theories as well post - modernist and Cyborg feminist perspectives. Friedan (1974), Rossi (1970) and Will Stone Craft (1975) are major advocates of the liberal school of feminism. This group of feminists focus on an ideal state where every citizen is liberally treated with respect, rights and opportunities. Their sympathetic position with the woman folk is hinged on advocacy for legal and political apparatus that will bring about the needed change in issues of gender, justice, laws and politics in favour of the women.

For the Post-modernists, where Radway (1984), Allen and Jones (1992) and Buttler (1990) are dominant, the modern trends accommodate both men and women performing cross gender roles and "even slide 
between gender identities". The Eco-feminists take a look at feminism from all environmental hazards women may suffer around the globe. Although Eco-feminists focus more on environment, the school has a holistic approach to feminism as it draws inference that the women folk suffer more from global crises resulting from racism, feminism, classism, imperialism, naturism, and specialism (Gaard \& Gruen 1993:pp.11-25).

The new trend of feminism is the Cyber feminist school which appropriates denial and deprivation suffered by the women as technological or scientific accidents. Donna Hardaway (1991) is an advocate of Cyborg feminist theory and her position is that women should learn to be women and not as men as against the input canvassed by what she called "western logos". In all, solutions proffered by the various schools are that woman should come out loud and position and utilize their competence and diverse qualities.

\section{Gender and Political Consciousness in So Long a Letter}

Two issues of concern are being raised by Mariama Ba in her work, So Long a Letter as she tackles constraints to African women's freedom, rights and advancement. A critical reading of the novella reveals a major source of conflict as the rapacious effect of polygamy and cultural censor or prohibition of a girl-child educational advancement. Although Senegal is the cultural setting in question, it is representative or symbolic of Africa and anywhere in the globe as the attitude towards polygamous practice and pre-judicial interpretation of girl-child educational qualification or attainment is quite uniform with regards to the handling or practice of polygamy by African men and women alike.

Latha (2004:54) captures the two issues in an insightful probe into the bottom line in his scholarly paper.

A discussion of So Long a Letter by the west African woman writer, Mariama Ba is used as a basis for highlighting the empowering and disempowering effects of particular types of education for women in the traditional African- Muslim context of Senegal. An examination of this issue in the novella would seem to indicate that the marginalization of Muslim women in this and other countries could be alleviated by a religious education which would investigate the difference between Islamic principles and cultural practices as our key focus.

At the onset, it is pertinent for us to raise question or embark on a close examination of the influence of religion on culture and vice versa in moulding the attitude, belief and understanding of the Senegalese or Africans on the issue of polygamy and western education as it affects the women. Latha has equally thrown open the discussion as he probes into the dichotomy between the two institutions. But it must be acknowledged that the concern of this paper is to critically analyse the novella along the authorial vision which exposes or condemns polygamous practice and constraints on the girl-child education.

So Long a Letter provides the basis for which the author represents the experiential account of polygamous practice and its effects on the psychology, mentality and emotion of the women victim. The real setting is Senegal but artistically the target is global especially where polygamy is religiously (Islamically) and culturally entrenched as a normal marital system. The novella is intended as a subtle and loud cry against a practice loathed or detested by women all over the world regardless of the skin colour, religious sect, tribal or ethnic extraction as illustrated by an adage of Yoruba that the loud prayer or supplication by women about being partners in a matrimonial home is not sincere. The problem is much more compounded by the grim reality that in many context, women are either barred from speaking up or do not have the courage to or means of rejecting the practice.

Mariama Ba's work could not be anything short of a subjective long narrative written to expose the evils of polygamy and factors militating against girl - child educational advancement. The writer- initiator is Ramatoulaye whose sentiment, idea, polemic and position represent the authorial attitude of Mariama Ba. She and her friend, Aissatou represent the women elite group members whose level of education knows no bound and for which they savour the joy, gain and enlightenment of being educated.

Ramatoulaye and Aissatou are among the few privileged educationally qualified women in West Africa as attested to by their profession- teachers in the higher institution. Ashcroft (1998:66) identifies inhibition of a girl-child educational advancement as a form of colonization. He describes the radical stance by Ramatoulaye and Aissatou as a form of decolonization, a process that is complex, continuous and conscious. In the same vein, Katract (1995: 255-256) describes the act as baleful influences and an oppression occasioned by denigrating traditions. And that it is for its debilitating effects that post-colonial women writers like Maria ma Ba search for alternative platform. He concludes that they are so armed by their class, background, level of education, political movement and commitment. It is instructive to note that it was due to Ramatoulaye's and Aissatou's educational advancement that they could revolt against polygamy and even roll out the drum to canvass for attainment of education by the girl-child without boundaries or restrictions. Their radical but enlightened stance see them severe their marital ties from their husbands against all odds.

Two factors seemed to have plagued the relationship or conjugal bond between Aissatou and Ramatoulaye and their spouses. One, polygamy in the consciousness of these spouses should have its limitations 
or boundary especially where the husband and wife are elite members of society. Apart from the fact that these women are highly educated, their husbands too are highly educated and members of the elite class - one a medical doctor, the other a labour official as the duo are well placed in their workplace. Unfortunately and ironically two, both of them are unanimous in their decision to take a second wife each. Their action/step eventually results to the destruction of their marriage bond of between ten and twelve years. The effect is obvious and uniform as their spouses too react to their decision through separation and severance of physical, conjugal and emotional tie. Ramatoulaye and her twelve children were separated from their husband and father - Modou while Aissatou, going extra mile files a divorce and moves to the United States with her four children. The success of the artistic work is enhanced by the verisimilitude of the story - painting of a realistic and experiential account. Miller (1997:6) hints at this when he observes that there is a semblance in the artistic world and Ba's life experiences. And Latha puts a seal that "So Long a Letter may then be read as semi-biographical depiction of the life of a woman living in the specific socio-cultural milieu of a particular time of her country's history." To all intent and purposes, the novella foregrounds gender and political consciousness of a female writer whose experiential account provides a semblance of a true life story either as a direct or implied victim. Maria ma Ba's uninterrupted monologue is designed as a political pamphlets resplendent of artistic production with which she whips up global sentiment and condemnation of cultural - cum Islamic practices with which men and women alike indulge to infringe on the rights, freedom and advancement of an African woman. To underscore the symbolic import of the novel and its ideological commitment and polemics, the author in an interview with Stringer (1996:58) refers to the novella as a cry from the heart of all women.

\section{Women vs Women in So Long a Letter}

Although Maria ma Ba takes a swipe at the deprivation of women by cultural or religious institution, there appears to be underlying voice on the issue of gender subjugation in the narrative of the novella. It is discernible in the artistic world of So Long a Letter that women are the victim and prey on one hand while women as well are the instrument or implementer of the cultural prejudices against women. The author in her work invites the world to behold and reject the culture of oppression, colonization and deprivation of the girlchild in her educational advancement; she equally invites the world to condemn and repudiate polygamy as inhibiting and limiting in its rapacious influence on the family spouses and destroying the bond of marriage and by implication causing irreparable damage to the bond of joy, togetherness and happiness of the infected family.

But underlying the scenario narrated by Ramatoulaye as the voice of Maria ma $\mathrm{Ba}$ is the instrumentality of women in destroying the joy of fellow women and by extension men as well. The second category of women opposed to Aissatou and Ramatoulaye and of course, Maria ma Ba and her elite corps of women of African descent and the world over are the in-laws as exemplified by Modou's and Mawdo's mother -in-laws. Gives an insightful character sketch this way:

Ramatoulaye: The widowed Senegalese woman who after 25 years of marriage and 12 children narrates the story of her psychological abandonment by her husband, who takes a second wife.

Modou: The husband of Ramatoulaye and of Binetou. He was well educated, handsome, and charming. For his own selfish desires, he marries Binetou and cuts ties with his 12 children and first wife, Ramatoulaye. He later dies of a heart attack.

Mawdo: Ex-husband of Aissatou. After being pressured by his mother, Mawdo follows Muslim tradition of polygamy and marries a young girl named Nabou, who is also his first cousin. He is Modou's long-time friend and a doctor.

Aissatou: Ramatoulaye's best friend, to whom the letter is addressed. She divorced Mawdo because she did not believe in polygamy; Her divorce is symbolic because it represents a new life for her. She succeeds in making a new life for herself. (www.categories:1981 novels Senegalese novels - Novels set in Senegal Heinemann (publisher) books)

The mother in-laws are cultural bigots who are normally and sentimentally jealous of their son's wives. On the issue of educational attainment or qualification of the girl-child and the status of their son's wives their resentment is registered in their attitude, opinion and action. Their influence on their sons marrying second wives was weighty even though they merely hid under cultural and religious injunctions to settle score with their son's wives. Steady (1981:34) in his similar observation concludes:

Females in senior positions in families have a great deal of authority. Aunty Nabou, Aissatou's motherin-law uses her position to coerce her educated son to marry a second wife of her choice, thereby destroying his first marriage, which had been based on love as well as intellectual compatibility.

On one hand, the practice of polygamy and wo/man prey and implementers underscore the place of education and cultural or religious influence. Ramatoulaye, after losing her husband rejects offer from Tamsir to marry him on the ground that he, Tamsir already had three wives even though his religion, Islam permits him to marry four. There is the economic angle to it which of course Islam spells out as one of the conditions for a 
man to marry up to four wives. Because Ramatoulaye is educated in both western and Koranic ways, she is able to tell Tamsir to his face the grim reality of his proposal to her.

What of your wives, Tamsir? Your income cannot meet their needs with those of your numerous children. To help you out with your financial obligation, one of your wives dyes, another sells fruits, the third untiringly turns the handle of her sewing machine (So Long a Letter P.58)

This was not the position of Binetou and her counterpart in the train of polygamy and those propping them, their mother - in- laws. Their 'ignorant/emotional' situation might be one major factor that encourages their arrangement. Aissatou's mother- in- law confirms this as she flays acquisition of western education by the female child. "To tell the truth, a woman does not need too much education. In fact I wonder how a woman can earn her living talking from morning till night. "(So Long a Letter p.30)

Perhaps it is this mother's influence that affects even the thinking capacity of some men/husbands in deciding for his daughters to acquire education. Ramatoulaye could not but wonder aloud why men would be procrastinating on the education of their daughters.

We have a right, just as you have, to education, which we ought to be able to pursue to the farthest limits of our intellectual capacities. We have a right to equal well-paid employment to equal opportunities. The right to vote is an important weapon (p.61)

We have a similar experience in Purple Hibiscus by Chiamamanda Adichie though with a slight variance. Eugene's people would want him to marry another wife because his wife could not give him more children having suffered several miscarriages. This is an Igbo cultural setting which encourages bearing more children especially when a man is seen to be more successful as it obtains in other African setting. But Eugene, unlike Modou and Mawdo would not give in to the pressure from his people, Beatrice's in-laws.

Maria Ma Ba emphasizes the relevance of education not just to the girl-child but to humanity as a whole: The power of books, marvelous invention of man's astute intelligence. Various signs associated with sounds moulding the word. Arrangement of words from which idea, thought, history, science, life springs out. Unique instrument of relationship and culture unequalled means of giving and receiving. Books knit together generations in the same continuous labour towards progress. (So Long a Letter P.52).

And personifying education and its teachers, Ramatoulaye comments in apparent reference to sense of freedom and choice at a critical time:

Aissatou, I will never forget the white woman who was the first to desire for us an uncommon destiny.... we were true sisters destined for the same mission of emancipation. To lift us out of the bug of tradition, superstition and custom, to make us appreciate a multitude of civilizations without renouncing our own, to raise our vision of the world, cultivate our personalities, strengthen our qualities, to make up for our inadequacies, to develop universal moral values in us: these were the aims of our admirable headmistress. (P.15 - 16).

It is a world without order where woman are forced on men as first, second, third or fourth wives and where girl - child education is inhibited or even atimes prohibited by cultural or individual and sexist prejudice. The damage polygamy has caused and still capable of causing is incalculable. This is what Aissatou captures in her anger:

Princes master their feelings to fulfill their duties. Others bend their heads and in silence, accept a destiny that oppresses them. That, briefly put is the internal ordering of our society; with its absurd divisions. I will not yield to it. I cannot accept what you are offering me today in place of the happiness we once had. You want to draw a line between heart felt love and physical love. I say that there can be no union of bodies without the hearts acceptance, however little that may be. If I can procreate without loving, merely to satisfy the pride of your declining mother, then I find you despicable. I am stripping myself of your love, your name clothed in my dignity, the only worthy garment, I got my way. (So Long a Letter pp.31- 32).

So Long a Letter is a realistic work of art. The work is a fictionalized real life experience partly of the author herself and that of the people around her. The diction is clear and direct as the author educates the readers about the plight of women under polygamous set up. In doing this, Mariama Ba argues for the womenvictims but against men and women who indulge in polygamy under religious or cultural guise. The novella provides a solution or a way out for women in a polygamous set up through formal education. The author clearly states that sex should not be a barrier for the acquisition of western formal education especially by the girl-child even interms of choice of course of study.

The tone is inciting and lamenting as the author sympathizes with the victims of polygamy. She equally attempts to awaken the consciousness in women all over the world to rise against polygamous practices. There is political undertone as the author takes the fight to all that matters politically with the intent of legislating against polygamy. It is a letter meant to warn, caution, educate and persuade young men and women against polygamous practice. 


\section{Conclusion}

The paper is a contribution to the growing body of critical works on So Long a Letter as a masterpiece. It further identifies polygamous practice as a bane of a united home or family which by implication fragments or terrorizes society because it is the families that make society. Textual analysis is limited to So Long a Letter and the implication of polygamy for African women. The import of the paper is it being used as a tool of education, sensitization and mobilization for men and women on the evils of polygamous practice. It is another effort at educating and soliciting the collaboration of the global community in the fight against polygamy.

\section{References}

[1]. Mariama Ba, M. So Long a Letter Translated by Modupe Bode-

[2]. Thomas (London: Heinemann 1980)

[3]. Nwapa, F. Efuru (London: Heinemann Books Ltd. 1966)

[4]. Alkali, Z The stillborn (London: Longman Drumbeat. 1984)

[5]. Adichie, C. Purple hibiscus (London: HarperCollins. 2003)

[6]. Achebe, C. (1958) Things fall apart (Britain: Cambridge University Press.

[7]. Ouloguem, Y. Bound to violence (London: Heinemann 1962)

[8]. Osofissan, F. Morountodun (Ibadan: Longman Nigeria. 1982)

[9]. Ousmane, S. God's bits of wood (London: Heinemann 1962)

[10]. Chukwuma, H. Feminism in African Literature: essay on criticism (ed). Abaka: Belpot.(ix) (1994)

[11]. Nnolim, C. "A house divided" in Chukwuma Helen (ed). Feminism in African Literature: essay on criticism. Abaka: Belpot 1994

[12]. Sarikakis, K. et al. Feminist theory and research. Stacks C032indd 2008504

[13]. Anzaldua, G. La consciencia de la mestiza[The conscience of Mestiza]: Towards a new consciousness. In Sarikakis, K. et al.(2008) Feminist theory and research. Stacks C032indd (1990)

[14]. Kolawole, M.E womanism and African consciousness. Trenton,NJ: African World Press .(1997)

[15]. Oyewumi, O.(Ed.). African women and feminism: Reflecting on the politics of sisterhood.Trenton,NJ: African World Press. (2003).

[16]. Faderman, L. Surpassing the love of men. New York: Morrow. (1981).

[17]. Friedman, B. The feminine mystique. New York: Dell. (1974).

[18]. Rossi, A.S.(Ed.). Essays on sex equality: John Stuart Mill\& Harriet Taylor Mill. Chicago: University of Chicago Press. (1970).

[19]. Wollstonecraft, M A vindication of the rights of women. In C.H. Poston (Ed.), New York: Norton. .(1975).

[20]. Radway, J. Reading the romance: Women, patriarchy and popular literature. Chapel Hill: University of North Carolina Press. (1984).

[21]. Allen, D.(n.d.). Media without democracy and what to do about it. Women's Institute for Freedom of the Press, 3306 Ross Place, NW, Washington, D.C.2008.

[22]. Butler, J. Gender trouble. New York: Routledge. (1990).

[23]. Gaard, G.,\& Gruen, L. Ecofeminism: Towards global justice and planetary health. Feminism and ecology issue. Society and Nature: The International Journal of Political Ecology, 2,1-35. (1993)

[24]. Haraway, D.J. Simians, cyborgs, and women: The reinvention of nature. New York: Routledge. (1991).

[25]. Latha, R.H. Mariama Ba's So Long a Letter and the educational empowerment of muslim women. South Africa: Acta Academica. (2004)

[26]. Ashcroft. B., G. Griffiths \& H. Tiffin Key concepts in post-colonial studies. London: Rutledge. (1998)

[27]. Katrak, H.K. Decolonizing culture: toward a theory for post-colonial women's texts. Ashcroft et al (eds) 1995:255-258

[28]. Miller, M K F My mothers/my selves: reading a tradition of West African women's autobiography. Research in African Literatures 1997, 28:5-16..

[29]. Stringer, S. The Senegalese novel by women (New York: Peter Lang. 1996)

[30]. www.categories:1981 novels Senegalese novels - Novels set in Senegal Heinemann (publisher) books

[31]. Steady, F.C. The black woman cross-culturally. Cambridge, Mass: Schenkman. 1981 